\title{
Effect of Cooling Root-Zone Temperature on Growth, Yield and Nutrient Uptake in Cucumber Grown in Hydroponic System During Summer Season in Cooled Greenhouse
}

\author{
Muthir S. Al-Rawahy ${ }^{1}$, Salim A. Al-Rawahy ${ }^{2}$, Yaseen A. Al-Mulla ${ }^{2,3} \&$ Saleem K. Nadaf $^{4}$ \\ ${ }^{1}$ Ministry of Agriculture \& Fisheries, Sultanate of Oman \\ ${ }^{2}$ Department of Soils, Water and Agricultural Engineering, College of Agriculture \& Marine Sciences, Sultan \\ Qaboos University, Sultanate of Oman \\ ${ }^{3}$ Remote Sensing and GIS Research Center, Sultan Qaboos University, Sultanate of Oman \\ ${ }^{4}$ Oman Animal \& Plant Genetic Resources Center, The Research Council, Sultanate of Oman \\ Correspondence: Muthir S. Al-Rawahy, Directorate General of Agriculture \& Livestock Research, Ministry of \\ Agriculture \& Fisheries, Sultanate of Oman. Tel: 968-2689-3132. E-mail: marwan07@live.com
}

\author{
Received: September 13, $2018 \quad$ Accepted: October 15, $2018 \quad$ Online Published: December 15, 2018 \\ doi:10.5539/jas.v11n1p47 \\ URL: https://doi.org/10.5539/jas.v11n1p47
}

The research is financed by Agriculture \& Fisheries Development Fund (AFDF) of the Ministry of Agriculture \& Fisheries, Sultanate of Oman and part of PhD thesis for submission to the Sultan Qaboos University, Sultanate of Oman.

\begin{abstract}
Optimum cool root zone temperature positively influences the production of greenhouse vegetables grown during summer/high temperature period under hydroponics system. Hence, the effect of root-zone temperature was investigated on the growth, yield and nutrient uptake of cucumber (Cucumis sativus L.) plants grown in pots filled with perlite medium under recirculating hydroponic system in greenhouse during summer period (June-August) in two consecutive years 2016/2017 and 2017/2018 using three cooling treatments-T1 $\left(22^{\circ} \mathrm{C}\right), \mathrm{T} 2$ $\left(25^{\circ} \mathrm{C}\right)$ and $\mathrm{T} 3\left(28^{\circ} \mathrm{C}\right)$ and non-cooled treatment $\mathrm{T} 4\left(33^{\circ} \mathrm{C}\right)$ as control in Randomized Complete Design (RCD). All the treatments received the same nutrient concentrations. Significant $(p<0.05)$ differences were observed for all the characters viz. plant height, leaf number $/ \mathrm{m}^{2}$, chlorophyll content, leaf area $\left(\mathrm{cm}^{2}\right)$, fruit number $/ \mathrm{m}^{2}$, yield $(\mathrm{t} / \mathrm{gh})$, fresh $(\mathrm{g})$ and dry matter weight $(\mathrm{g})$ of shoot and root at all cooled root-zone temperatures as compared to control in both the years. Plants at cooled root-zone temperature (RZT) of $22{ }^{\circ} \mathrm{C}$ gave high number of fruits $/ \mathrm{m}^{2}$ to the extent of 180 in $2016 / 2017$ and 220 in $2017 / 2018$ followed by that at $25^{\circ} \mathrm{C}(167,221)$ and $28^{\circ} \mathrm{C}(178,143)$ as compared to those in control $\left(33^{\circ} \mathrm{C}\right)(101,133)$ in both the years. Similarly, highest fruit yields were found at cooled RZT of $22{ }^{\circ} \mathrm{C}(5.0 \mathrm{t} / \mathrm{gh})$ and $28^{\circ} \mathrm{C}(4.7 \mathrm{t} / \mathrm{gh})$ in the first year and $22{ }^{\circ} \mathrm{C}(6.1 \mathrm{t} / \mathrm{gh})$ and $25^{\circ} \mathrm{C}(6.0 \mathrm{t} / \mathrm{gh})$ in the second year. The plants at cooled RZT responded positively and significantly $(\mathrm{p}<0.05)$ in the uptake of all nutrient elements in shoots and roots in comparison with those at non-cooled RZT in both years.
\end{abstract}

Keywords: root-zone, temperature, growth, yield, hydroponics, cucumber

\section{Introduction}

While the air temperature is one of the most important environmental elements for the altering secondary metabolism in the plants for production (Kaplan et al., 2004; Zobayed et al., 2005; Ramakrishna \& Ravishankar, 2011), the temperature at the root-zone also influences the growth and chemical composition of many plants (Adebooye et al., 2010; Malik et al., 2013; Yan et al., 2013; Sakamoto \& Suzuki, 2015a, 2015b). One of the characteristics of hydroponic cultivation is its ability to control the temperature of the nutrient solution around the root system using heaters or cooling spirals, to increase or decrease the temperature, respectively. During the midday period, in the hot summers, the root-zone temperature of hydroponic systems often exceeds $30^{\circ} \mathrm{C}$. The root-zone temperature can often reach $35^{\circ} \mathrm{C}$ when the air temperature is $38{ }^{\circ} \mathrm{C}$. This was strongly found to suppress the plant growth process and reduce uptake of water and nutrients (Mozafar et al., 1993; Marschner et al., 1996; Stoltzfus et al., 1998). Several studies on different species have shown that plant growth is greatly 
influenced by root zone temperature (Lyr \& Garbe, 1995; Lahti et al., 2005; Solfjeld \& Johnsen, 2006; Diaz-Perez et al., 2007; Nxawe et al., 2009). Although, plant growth is controlled by various factors, root zone temperature and nutrient supply indicate that RZT is crucially an important factor in plant nutrient uptake. In view of the above, the study was designed to investigate the effect of root-zone temperature on the growth and yield of cucumber (Cucumis sativus L.).

\section{Materials and Methods}

Seeds of cucumber variety namely; Reema F1 (Trust Seeds ) were sown in 72 hole trays on 11/5/2016 and 9/5/2017 and transplanted after 10 days in polyfoam pots filled with perlite medium under recirculating hydroponic system in the greenhouse of $270 \mathrm{~m}^{2}(9 \mathrm{~m} \times 30 \mathrm{~m})$ during summer (June-August) in two consecutive years 2016/2017 and 2017/2018 at the research site of the Directorate General of Agriculture and Livestock Research, Ministry of Agriculture \& Fisheries, located at Rumais, Wilayat Barka, South Batinah Governorate of Oman. Three cooling treatments were applied; T1 $\left(22^{\circ} \mathrm{C}\right)$, T2 $\left(25^{\circ} \mathrm{C}\right)$ and T3 $\left(28^{\circ} \mathrm{C}\right)$ through cooling nutrient solution along with non-cooled treatment, $\mathrm{T} 4\left(33^{\circ} \mathrm{C}\right)$ as control. The treatments were arranged in Randomized Complete Design (RCD) with four replications. All the treatments received the same nutrient concentrations. The experiment layout and fertigation were followed as mentioned in Al Rawahy et al. (2018).

Parameters such as plant height $(\mathrm{cm})$, leaf number $/ \mathrm{m}^{2}$, leaf area index $\left(\mathrm{cm}^{2}\right)$, chlorophyll (SPAD values), fruit number $/ \mathrm{m}^{2}$, yield $(\mathrm{t} / \mathrm{gh})$, shoot fresh weight $(\mathrm{g})$, root fresh weight $(\mathrm{g})$, shoot dry weight $(\mathrm{g})$, root dry weight $(\mathrm{g})$, shoot dry weight $(\%)$, root dry weight $(\%)$, fruit length $(\mathrm{cm})$, fruit diameter $(\mathrm{cm})$ and total soluble solids (TSS) (\%) were measured besides nutrient elements in shoots and roots including $\mathrm{N}, \mathrm{P}, \mathrm{K}, \mathrm{Ca}$ and $\mathrm{Mg}$ (AOAC, 1984) determined on dry matter basis. Analysis of variance (ANOVA) and multiple comparisons (least significant difference-LSD) were performed using GenStat $12^{\text {th }}$ edition (VSN Intentional, 2011)

\section{Results}

\subsection{Growth Parameters}

\subsubsection{Plant height}

Plant height varied from $141 \mathrm{~cm}$ to $173.4 \mathrm{~cm}$ and from $132 \mathrm{~cm}$ to $157.4 \mathrm{~cm}$ in 2016/2017 and 2017/2018, respectively, during summer (June-August) with significant $(\mathrm{p}<0.05)$ differences among root-zone temperatures(RZT) (Table 1). The cucumber plants in the cooled root-zone temperatures $22{ }^{\circ} \mathrm{C}, 25^{\circ} \mathrm{C}$ and $28^{\circ} \mathrm{C}$ produced significantly highest $(\mathrm{p}<0.05)$ plant height as compared to that in control (non-cooled root-zone temperature, $33{ }^{\circ} \mathrm{C}$ ) in both years. The highest plant height was found at cooled root-zone temperature of $22{ }^{\circ} \mathrm{C}$ to the extent of $173.4 \mathrm{~cm}$ followed by $170.3 \mathrm{~cm}$ at cooled root-zone temperature of $28{ }^{\circ} \mathrm{C}$ whereas the lowest plant height was found at $33{ }^{\circ} \mathrm{C}(141 \mathrm{~cm})$ in $2016 / 2017$ ( $\left.\mathrm{p}>0.05\right)$. The response trend was not the same in $2017 / 2018$ where the plants at $22^{\circ} \mathrm{C}$ produced higher plant height $(157.4) \mathrm{cm}$ followed insignificantly by that at $25^{\circ} \mathrm{C}(157.5 \mathrm{~cm})$ and it was significantly the lowest at $33^{\circ} \mathrm{C}(127 \mathrm{~cm})$.

\subsubsection{Leaf Number}

Significant $(\mathrm{p}<0.05)$ differences were observed in leaf number per plant between the root-zone temperatures in both years, 2016/2017 and 2017/2018. During the first year leaf number per plant ranged from 27 to 30 whereas in the second year it varied from 29 to 34 (Table 1). The plants at $22{ }^{\circ} \mathrm{C}$ and $25^{\circ} \mathrm{C}$ gave more number of leaves per plant (30 and 29) whereas the lowest number was found at $33^{\circ} \mathrm{C}(27)$ during the first year. Same trend was observed in second year with cooled root-zone temperatures except for root-zone at $28^{\circ} \mathrm{C}$ in which the lowest leaf number was observed (29). Significantly higher number of leaves per plant was recorded with root-zone temperatures $22{ }^{\circ} \mathrm{C}$ and $25^{\circ} \mathrm{C}$ ( 34 leaves per plant) as compared to that at other root zone temperatures. 
Table 1. Effect of root-zone temperature (RZT) on plant height and leaf number/plant of cucumber grown under hydroponic closed system during summer (June-August) in cooled greenhouse

\begin{tabular}{|c|c|c|c|c|}
\hline \multirow{2}{*}{$\mathrm{RZT}\left({ }^{\circ} \mathrm{C}\right)$} & \multicolumn{2}{|c|}{ Plant height $(\mathrm{cm})$} & \multicolumn{2}{|c|}{ Leaf Number/Plant } \\
\hline & First year 2016/2017 & Second year 2017/2018 & First year 2016/2017 & Second year 2017/2018 \\
\hline 22 & $173.4 \mathrm{a}$ & $157.4 \mathrm{a}$ & 30 & 34 \\
\hline 25 & $155 \mathrm{~b}$ & $157.5 \mathrm{a}$ & 29 & 34 \\
\hline 28 & $170.3 \mathrm{a}$ & $132 \mathrm{~b}$ & 28 & 29 \\
\hline 33 & $141 \mathrm{c}$ & $127 \mathrm{~b}$ & 27 & 30 \\
\hline \multicolumn{5}{|c|}{ Statistical Parameters } \\
\hline F-test & $* *$ & $* *$ & $* *$ & $* *$ \\
\hline $\operatorname{LSD}(5 \%)$ & 12.2 & 10.9 & 1.3 & 1.1 \\
\hline $\mathrm{CV} \%$ & 17.2 & 6.9 & 10.6 & 8.1 \\
\hline
\end{tabular}

\subsubsection{Leaf Area $\left(\mathrm{cm}^{2}\right)$}

Leaf area of any plants reflects to amount of photosynthesis and assimilations rates. Leaf area in 2016/2017 and 2017/2018 was higher in all the cooled root-zone temperatures tested as compared to control with significant(p < 0.05 ) differences. Leaf area was higher in the second year 2017/2018 among the root-zone temperatures. The leaf area varied from 205.1 to $346.9 \mathrm{~cm}^{2}$ and from 207 to $356.6 \mathrm{~cm}^{2}$ during 2016/2017 and 2017/2018, respectively. Leaf area was in general higher at the root-zone temperature of $22{ }^{\circ} \mathrm{C}$ in both years $\left(346.9 \mathrm{~cm}^{2}\right.$ and $\left.356.6 \mathrm{~cm}^{2}\right)$ and lowest area was at non-cooled root-zone temperature, $33{ }^{\circ} \mathrm{C}\left(205.1 \mathrm{~cm}^{2}\right.$ and $\left.207.0 \mathrm{~cm}^{2}\right)$ (Figures 1a and $b)$.

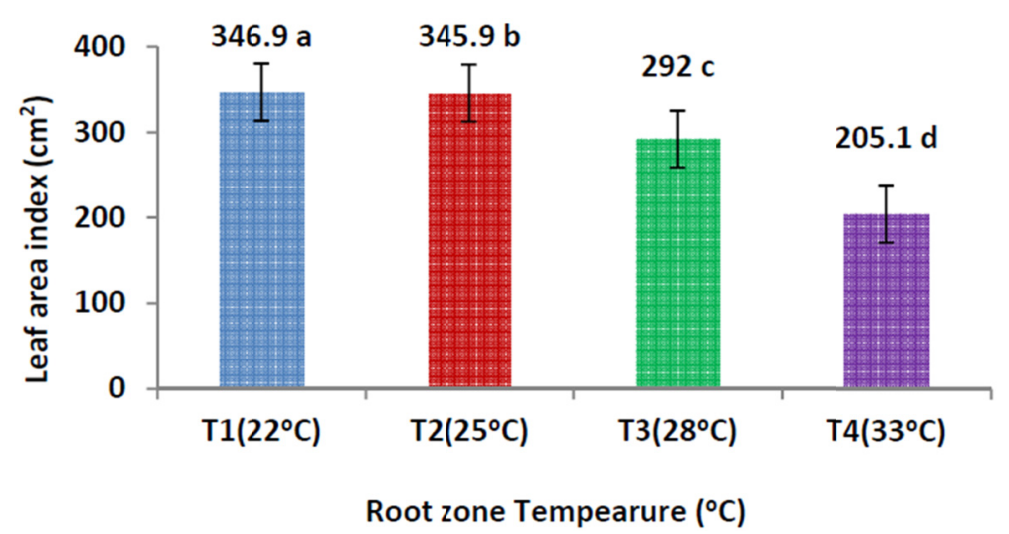

Figure 1a. Effect of root-zone temperature (RZT) on leaf area $\left(\mathrm{cm}^{2}\right)$ at vegetative stage of cucumber plants grown hydroponically during summer (June-August) 2016/2017

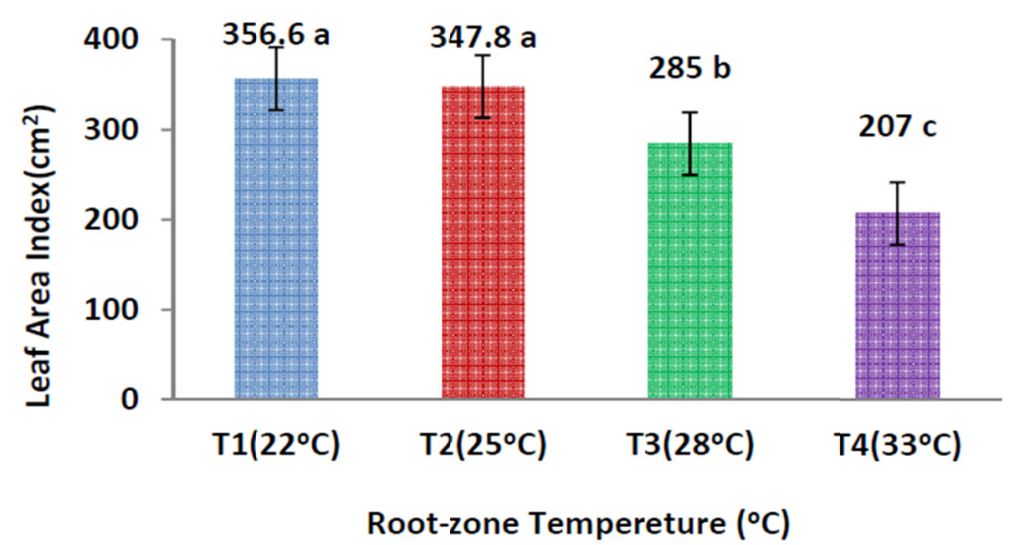

Figure1b. Effect of root-zone temperature (RZT) on leaf area $\left(\mathrm{cm}^{2}\right)$ at vegetative stage of cucumber plants grown hydroponically during summer (June-August) 2017/2018 


\subsubsection{Chlorophyll Content}

Color pigmentation in plants, especially in the form of chlorophyll, is important for their plant growth and development. Significant $(\mathrm{p}<0.05)$ differences were observed in chlorophyll content as SPAD values between root-zone temperatures of cucumber in both years, 2016/2017 and 2017/2018. In 2016/2017, chlorophyll content varied from 43 to 48 SPAD values whereas in the second year it ranged from 43.1 to 49.1 SPDA values. Plants at root-zone temperatures of $22{ }^{\circ} \mathrm{C}$ and $25^{\circ} \mathrm{C}$ produced higher chlorophyll content in both years of experiments as compared to root-zone temperature of $28{ }^{\circ} \mathrm{C}$ and control $\left(33^{\circ} \mathrm{C}\right)$ which were fluctuating and inconsistent. Highest chlorophyll content was given by plants of cooled root-zone temperature of $\left(25^{\circ} \mathrm{C}\right)$ with 48 SPAD values followed by plants of root-zone temperature of $\left(22^{\circ} \mathrm{C}\right.$; $45.3 \mathrm{SPAD}$ values). The lowest was given by plants of cooled root-zone temperature of $28^{\circ} \mathrm{C}$ (43 SPAD values) in 2016/2017 (Figure 2a). Same trend was observed in $2017 / 2018$ where plants of cooled root-zone temperatures at $22{ }^{\circ} \mathrm{C}$ and $25{ }^{\circ} \mathrm{C}$ produced higher chlorophyll content as compared to the plants of control. Plants at root-zone temperature of $22{ }^{\circ} \mathrm{C}$ gave the highest chlorophyll content with $49.1 \mathrm{SPAD}$ values followed by the plants at root-zone temperature of $25^{\circ} \mathrm{C}$ (47.4 SPAD values) and the lowest chlorophyll content was found in the control $\left(33^{\circ} \mathrm{C}\right)$ with $43.1 \mathrm{SPAD}$ values (Figure 2b).

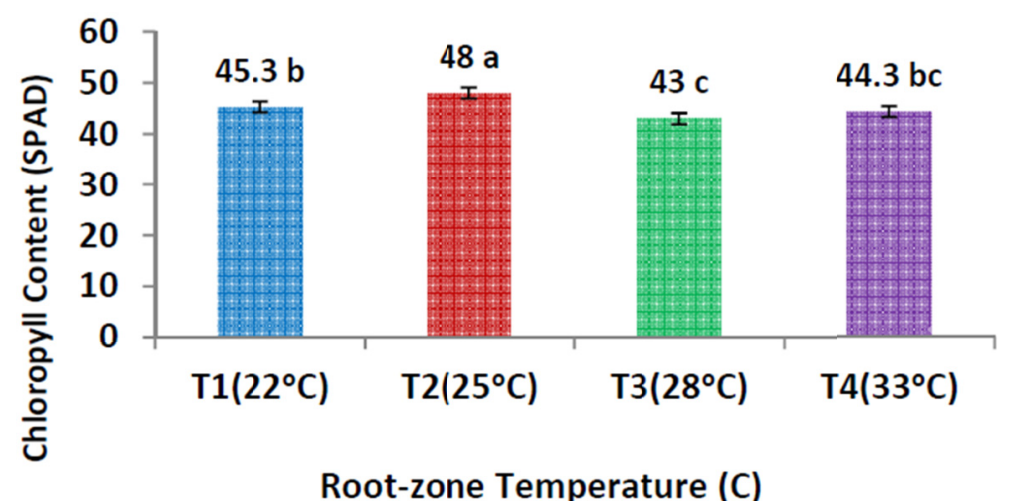

Figure 2a. Effect of root-zone temperature (RZT) on chlorophyll content as SPAD values of cucumber plants grown hydroponically during summer (June-August) first year 2016/2017

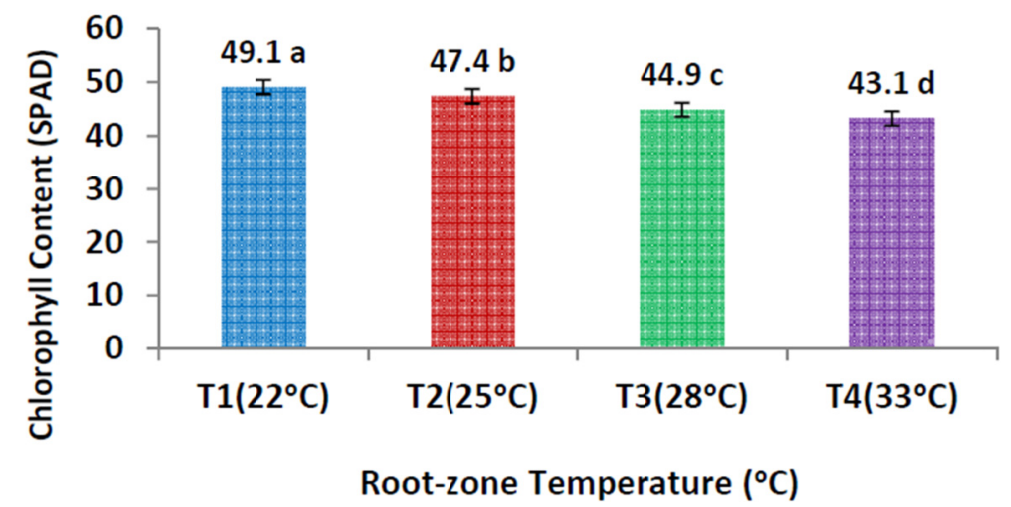

Figure 2b. Effect of root-zone temperature (RZT) on chlorophyll content as SPAD values of cucumber plants grown hydroponically during summer (June-August) second year 2017/2018

\subsubsection{Fruit Number per $\mathrm{m}^{2}$}

Fruit number varied from 101 to 180 with significant $(p<0.05)$ differences between the root-zone temperatures tested in the first year, 2016/2017. All the plants of cooled root-zone temperatures $22{ }^{\circ} \mathrm{C}, 25{ }^{\circ} \mathrm{C}$ and $28^{\circ} \mathrm{C}$ produced higher number of fruits compared to plants at control $33{ }^{\circ} \mathrm{C}$. The highest fruit number per $\mathrm{m}^{2}$ was produced by plants of cooled root-zone temperature of $22{ }^{\circ} \mathrm{C}\left(180 / \mathrm{m}^{2}\right)$ followed by the plants at $28{ }^{\circ} \mathrm{C}\left(178 / \mathrm{m}^{2}\right)$ and the lowest was found at control $\left(33^{\circ} \mathrm{C}\right)\left(101 / \mathrm{m}^{2}\right)$ (Table 2). With regard to second year $2017 / 2018$, the 
results showed same trend with increased number of fruits $/ \mathrm{m}^{2}$ at tested treatments. Fruit numbers varied from 133 to 221 with significant $(\mathrm{p}<0.05)$ differences between all the root-zone temperatures. Plants of cooled root-zone temperatures of $22{ }^{\circ} \mathrm{C}, 25^{\circ} \mathrm{C}$ and $28{ }^{\circ} \mathrm{C}$ produced higher fruit numbers $/ \mathrm{m}^{2}$ as compared to plants in control. Plants of cooled root-zone temperature of $25{ }^{\circ} \mathrm{C}$ gave the highest fruits number of $221 / \mathrm{m}^{2}$ followed by plants at cooled root-zone temperature of $22{ }^{\circ} \mathrm{C}\left(220 / \mathrm{m}^{2}\right)$ as compared to those in control with $133 / \mathrm{m}^{2}$ (Table 2).

\subsubsection{Yield (t/gh)}

Significant $(\mathrm{p}<0.05)$ yield differences were observed between the root-zone temperatures in cucumber in both years of experiment, 2016/2017 and 2017/2018. However, all the plants of cooled root-zone temperatures; $22^{\circ} \mathrm{C}$, $25^{\circ} \mathrm{C}$ and $28{ }^{\circ} \mathrm{C}$ produced higher yield as compared to plants in control. The yield varied from $2.8 / \mathrm{gh}$ to $5.0 \mathrm{t} / \mathrm{gh}$ during the first year 2016/2017. The highest yield was produced by plants of cooled root-zone temperature of 22 ${ }^{\circ} \mathrm{C}$ with $5.0 \mathrm{t} / \mathrm{gh}$ followed by the plants at root-zone temperature of $28{ }^{\circ} \mathrm{C}$ with $4.7 \mathrm{t} / \mathrm{gh}$ as compared to those in the control which was the least $(2.8 \mathrm{ton} / \mathrm{gh})$. In the second year the results showed the same trend as first year with improved yield of plants in all treatments tested. The cucumber yield ranged between $3.5 \mathrm{t}$ and $6.1 \mathrm{t} / \mathrm{gh}$ with significant differences $(p<0.05)$ between the root-zone temperatures. Highest yield was produced by plants at root-zone temperature of $22{ }^{\circ} \mathrm{C}(6.1 \mathrm{t} / \mathrm{gh})$ followed by the plants at root-zone temperature of $25^{\circ} \mathrm{C}(6.0 \mathrm{t} / \mathrm{gh})$ and $28{ }^{\circ} \mathrm{C}(3.8 \mathrm{t} / \mathrm{gh})$ as compared to that in the control $\left(33^{\circ} \mathrm{C}\right)$ with $3.5 \mathrm{t} / \mathrm{gh}$ which was the least (Table 2). The increase in yield in the second year 2017/2018 was attributed more numbers of harvests made and lesser incidences of diseases and pest infestations than those in the first year. In general during summer season the production of cucumber would be normally low due to high temperatures. In the present experiment, on the contrary the cooled nutrient solutions tested had demonstrated to offer positive effects with the higher levels of production as compared to the production level in the non-cooled control.

Table 2. Effect of RZT on Fruit number $/ \mathrm{m}^{2}$ and yield ( $\left.\mathrm{t} / \mathrm{gh}\right)$ of cucumber grown in hydroponics, closed system during summer (June-August) in cooled greenhouse

\begin{tabular}{llllll}
\hline \multirow{2}{*}{ RZT $\left({ }^{\circ} \mathrm{C}\right)$} & \multicolumn{2}{c}{ Fruit number $/ \mathrm{m}^{2}$} & & \multicolumn{2}{c}{ Yield $(\mathrm{t} / \mathrm{gh})$} \\
\cline { 2 - 3 } 22 & First year 2016/2017 & Second year 2017/2018 & & First year 2016/2017 & Second year 2017/2018 \\
\hline 25 & $180 \mathrm{a}$ & $220 \mathrm{a}$ & & $5.0 \mathrm{a}$ & $6.1 \mathrm{a}$ \\
28 & $167 \mathrm{a}$ & $221 \mathrm{a}$ & & $4.4 \mathrm{a}$ & $6.0 \mathrm{a}$ \\
33 & $178 \mathrm{a}$ & $143 \mathrm{~b}$ & $4.7 \mathrm{a}$ & $3.8 \mathrm{~b}$ \\
\hdashline Statistical Parameters & $101 \mathrm{~b}$ & $133 \mathrm{~b}$ & $2.8 \mathrm{~b}$ & $3.5 \mathrm{~b}$ \\
F-test & $* *$ & & & $* *$ & $* *$ \\
LSD $(5 \%)$ & 44.5 & 53.0 & 1.2 & 1.5 \\
CV $\%$ & 18.5 & 19.1 & 18.5 & 20.3 \\
\hline
\end{tabular}

\subsubsection{Shoot Fresh Weight}

The effects of cooled root-zone temperature on shoot fresh weight of cucumber plants were highly significant ( $\mathrm{p}$ $<0.05$ ) among the treatments tested in the first year, 2016/2017. Plants of cooled root-zone temperature of $22^{\circ} \mathrm{C}$ and $25{ }^{\circ} \mathrm{C}$ produced higher shoot fresh weight as compared to the plants of non-cooled control with root-zone temperature of $33{ }^{\circ} \mathrm{C}$. The shoot fresh weight ranged from $188.1 \mathrm{~g}$ to $274.2 \mathrm{~g}$. The plants of cooled root-zone temperature of $25{ }^{\circ} \mathrm{C}$ gave $274.2 \mathrm{~g}$ /plant followed by plants of root-zone temperature of $22{ }^{\circ} \mathrm{C}$ with $264.1 \mathrm{~g}$ as compared to that in control with 188.1g (Table 3). With respect to second year, 2017/2018, no significant differences were observed in shoot fresh weight between the tested root-zone temperatures. Shoot fresh weight ranged from $208.8 \mathrm{~g}$ to $256.6 \mathrm{~g}$ with the highest shoot fresh weight at cooled root-zone temperature of $25^{\circ} \mathrm{C}$ $(256.6 \mathrm{~g})$ followed by that at $22^{\circ} \mathrm{C}(227.5 \mathrm{~g})$ as compared to the lowest of $208.8 \mathrm{~g}$ at control $33^{\circ} \mathrm{C}$ (Table 3 ).

\subsubsection{Root Fresh Weight}

The response of plants in terms of root fresh weight was similar in trend to that shown in terms of shoot fresh weight. Significant $(p<0.05)$ root fresh weights were obtained among the plants of cooled root-zone temperatures and those in control in the first year, 2016/2017. Plants at cooled root-zone temperature of $22^{\circ} \mathrm{C}$ gave the highest root fresh weight $(38.0 \mathrm{~g})$ followed by $25^{\circ} \mathrm{C}$ with $36.9 \mathrm{~g}$ and the least fresh root weight was at the control with $28.9 \mathrm{~g}$ (Table 3). During the second year, 2017/2018 no significant differences were observed in root fresh weight between the treatments (Table 3). 


\subsubsection{Shoot Dry Weight}

Shoot dry weight varied from $37.1 \mathrm{~g}$ to $49.3 \mathrm{~g}$ with significant $(\mathrm{p}<0.05)$ differences among the root-zone temperatures tested. Plants of cooled root-zone temperatures $22{ }^{\circ} \mathrm{C}, 25{ }^{\circ} \mathrm{C}$ and $28{ }^{\circ} \mathrm{C}$ gained more shoot dry weight than plants at non-cooled root-zone temperature of $33^{\circ} \mathrm{C}$ (control) in the first year, 2016/2017. Plants of cooled root-zone temperature $25{ }^{\circ} \mathrm{C}$ gave the highest shoot dry weight $(49.3 \mathrm{~g})$ followed by root-zone temperature $22{ }^{\circ} \mathrm{C}(48.7 \mathrm{~g})$. The lowest shoot dry weigh of $37.1 \mathrm{~g}$ was recorded at non-cooled root-zone temperature of $33^{\circ} \mathrm{C}$ (Table 4). In the second year, 2017/2018, shoot dry weight showed no any significant differences among the treatments tested (Table 4).

\subsubsection{Root Dry Weight (g)}

Significant $(p<0.05)$ effects of root-zone temperatures were noted in root dry weights in both the years. Plants of cooled root-zone temperatures showed more root dry weight than those at non-cooled root-zone temperature (control) in the first year $2016 / 2017$. Root-zone temperature of $22{ }^{\circ} \mathrm{C}$ produced highest root dry weight $(20.2 \mathrm{~g}$, $19.9 \mathrm{~g})$ followed by root-zone temperature of $25^{\circ} \mathrm{C}(19.9 \mathrm{~g}, 19.6 \mathrm{~g})$ in 2016/2017 and 2017/2018 respectively whereas the lowest root dry weight was found at non-cooled root-zone temperature of $33{ }^{\circ} \mathrm{C}$ (control) (Table 4).

Table 3. Effect of RZT on shoot and root fresh weight (g) of cucumber grown in hydroponics, closed system during summer (June-August) of 2016/2017 and 2017/2018 in cooled greenhouse

\begin{tabular}{|c|c|c|c|c|}
\hline \multirow{2}{*}{ Root-zone temperatures $\left({ }^{\circ} \mathrm{C}\right)$} & \multicolumn{2}{|c|}{ Year 2016/2017 } & \multicolumn{2}{|c|}{ Year 2017/2018 } \\
\hline & Shoot & Root & Shoot & Root \\
\hline 22 & $264.1 \mathrm{a}$ & $38.0 \mathrm{a}$ & 227.5 & 39.5 \\
\hline 25 & $274.2 \mathrm{a}$ & $36.9 \mathrm{a}$ & 256.6 & 36.0 \\
\hline 28 & $222.0 \mathrm{~b}$ & $34.8 \mathrm{~b}$ & 197.5 & 34.2 \\
\hline 33 & $188.1 \mathrm{~b}$ & $28.9 \mathrm{~b}$ & 208.8 & 31.1 \\
\hline \multicolumn{5}{|l|}{ Statistical Parameters } \\
\hline F-test & $* *$ & $* *$ & NS & NS \\
\hline LSD at 0.05 & 60.9 & 7.4 & - & - \\
\hline $\mathrm{CV} \%$ & 16.7 & 14.0 & 33.5 & 26.1 \\
\hline
\end{tabular}

Table 4. Effect of RZT on shoot and root dry weight (g) of cucumber grown in hydroponics, closed system during summer seasons (June-August) of 2016/2017 and 2017/2018 in cooled greenhouse

\begin{tabular}{|c|c|c|c|c|}
\hline \multirow{2}{*}{ Root-zone temperatures $\left({ }^{\circ} \mathrm{C}\right)$} & \multicolumn{2}{|c|}{ Year 2016/2017 } & \multicolumn{2}{|c|}{ Year 2017/2018 } \\
\hline & Shoot & Root & Shoot & Root \\
\hline 22 & $48.7 \mathrm{a}$ & $20.2 \mathrm{a}$ & 34.7 & $19.9 \mathrm{a}$ \\
\hline 25 & $49.3 \mathrm{a}$ & $19.9 \mathrm{a}$ & 35.7 & $19.6 \mathrm{a}$ \\
\hline 28 & $39.8 \mathrm{~b}$ & $17.6 \mathrm{~b}$ & 31.7 & $13.6 \mathrm{c}$ \\
\hline 33 & $37.1 \mathrm{~b}$ & $16.6 \mathrm{~b}$ & 29.0 & $17.5 \mathrm{~b}$ \\
\hline \multicolumn{5}{|l|}{ Statistical Parameters } \\
\hline F-test & $* *$ & $* *$ & NS & $* *$ \\
\hline LSD at 0.05 & 3.4 & 1.3 & - & 4.7 \\
\hline $\mathrm{CV} \%$ & 5 & 4.4 & 17.8 & 17.2 \\
\hline
\end{tabular}

\subsection{Nutrient Content}

\subsubsection{Nutrient Concentration and Uptake in Shoot}

Concentration and uptake of mineral elements in the shoot of cucumber were strongly affected by the interacting effects of root-zone temperature (RZT). Nevertheless, not all elements were affected to the same extent. Significant $(p<0.05)$ increases in nitrogen and calcium uptake were observed between the root-zone temperatures in cucumber shoots whereas there were no significant $(p>0.05)$ effects in uptake of phosphorus, potassium and magnesium elements between the root-zone temperatures in the first year 2016/2017. Nitrogen uptake was increased significantly with the cooled root-zone temperature of $22^{\circ} \mathrm{C}, 25^{\circ} \mathrm{C}$ and $28^{\circ} \mathrm{C}$ as compared 
to that at non-cooled root-zone temperature of $33{ }^{\circ} \mathrm{C}$. Higher nitrogen concentration was found at root-zone temperature of $22{ }^{\circ} \mathrm{C}(3.1 \%)$ and $25^{\circ} \mathrm{C}(3.0 \%)$ where the lowest nitrogen uptake was in non-cooled root-zone temperature of $33{ }^{\circ} \mathrm{C}(2.5 \%)$. On the other hand, shoot had higher calcium concentration at cooled root-zone temperature of $25^{\circ} \mathrm{C}$ with $4.1 \%$ than that at root-zone temperature of $22{ }^{\circ} \mathrm{C}$ with $3.9 \%$ while the lowest was that at non-cooled root-zone temperature of $33^{\circ} \mathrm{C}$ with $3.1 \%$. There were significant $(\mathrm{p}<0.05)$ effects during second year, 2017/18 in nitrogen, potassium and calcium uptakes in cucumber shoots among cooled root-zone temperatures as compared to those at control. Similar trend however, was observed in all the elements as during first year in respect of nitrogen, potassium and calcium uptakes, which were higher in cooled root-zone temperatures of $22{ }^{\circ} \mathrm{C}, 25^{\circ} \mathrm{C}$ and $28^{\circ} \mathrm{C}$ as compared to that non-cooled root-zone temperature of $33{ }^{\circ} \mathrm{C}$. Highest nitrogen uptake was found in cooled root-zone temperature of $22{ }^{\circ} \mathrm{C} 3.4 \%$ followed by $25{ }^{\circ} \mathrm{C}$ with $3.0 \%$ and 28 ${ }^{\circ} \mathrm{C}$ with $3.0 \%$. Potassium uptake was higher at cooled root-zone temperatures of $22{ }^{\circ} \mathrm{C}, 25{ }^{\circ} \mathrm{C}$ and $28{ }^{\circ} \mathrm{C}$ with $3.1 \%, 2.9 \%$ and $2.6 \%$, respectively (Figure 3a). No any significant effects were observed in phosphors and magnesium uptakes in all the root-zone temperatures during 2017/2018 (Table 3b). The results obtained indicated that concentrations of all nutrients elements in shoots at the end of the experiment were of lower magnitude as compared those at the initial stages of growth as all nutrient elements were accumulated in leaves and fruits of cucumber.

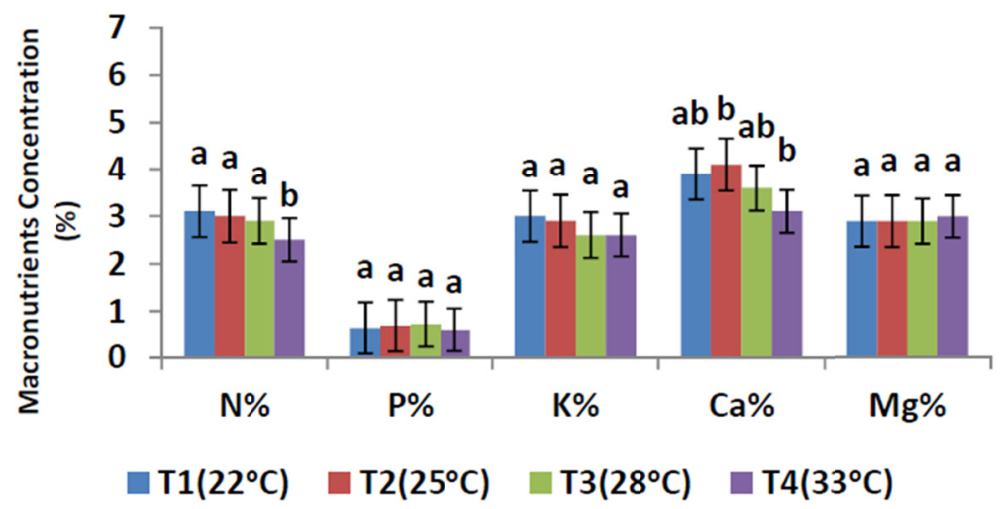

Figure 3a. Effect of root-zone temperatures on shoots nutrient concentration of cucumber plant grown in hydroponic closed system during summer (June-August) in 2016/2017

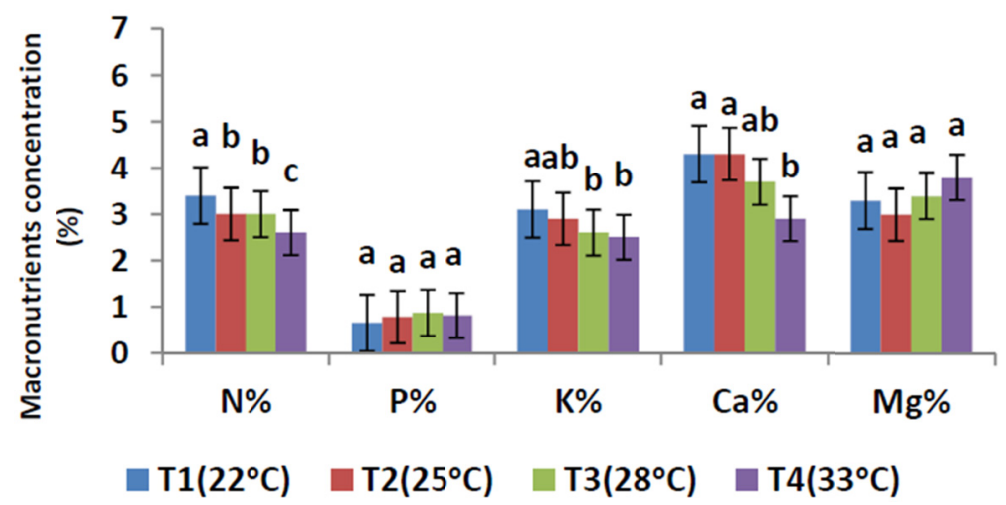

Figure 3b. Effect of root-zone temperatures on shoots nutrient concentration of cucumber plant grown in hydroponic closed system during summer (June-August) in 2017/2018

\subsubsection{Nutrient Concentration and Uptake in Root}

Significant $(p<0.05)$ nutrients element concentrations' uptakes were obtained in all the root-zone temperatures in cucumber roots in the first year. Nitrogen uptake was found significantly increased with cooled root-zone temperatures. The highest nitrogen uptake was found at cooled root-zone temperature of $22^{\circ} \mathrm{C}$ with $2.7 \%$ and 25 ${ }^{\circ} \mathrm{C}$ with $2.7 \%$ as compared to the lowest uptake recorded at non-cooled root-zone temperature of $33{ }^{\circ} \mathrm{C}(2.3 \%)$. 
Similar trend was seen in potassium and magnesium uptakes (Figure 4a). With regard to second year 2017/2018, the nutrient elements showed significant $(\mathrm{p}<0.05)$ uptake effects in roots of cucumber between the root-zone temperatures except for calcium element. The highest nitrogen uptake was found at cooled root-zone temperature of $22{ }^{\circ} \mathrm{C}(2.9 \%)$ followed by cooled root-zone temperature of $25^{\circ} \mathrm{C}(2.8 \%)$ as compared to that of $28{ }^{\circ} \mathrm{C}$ with $2.6 \%$. The lowest was found at non-cooled root-zone temperature of $33{ }^{\circ} \mathrm{C}(2.3 \%)$. Similar trends were noticed for phosphorus, potassium and magnesium uptakes. There were no significant effects in calcium uptake in roots of cucumber between the root-zone temperatures. The results thus indicated that concentrations of all nutrients elements in roots at the end of the experiment were lower as compared to those at the initial stages as all nutrient elements were accumulated in leaves and fruits of cucumber (Figure $4 b$ ).

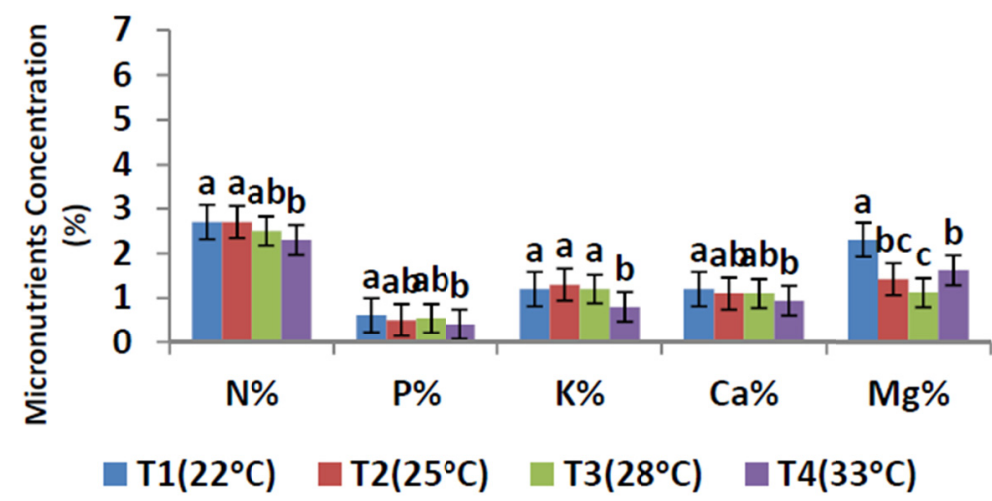

Figure 4a. Effect of root-zone temperatures on roots nutrient concentration of cucumber plant grown in hydroponic closed system during summer (June-August) in 2016/2017

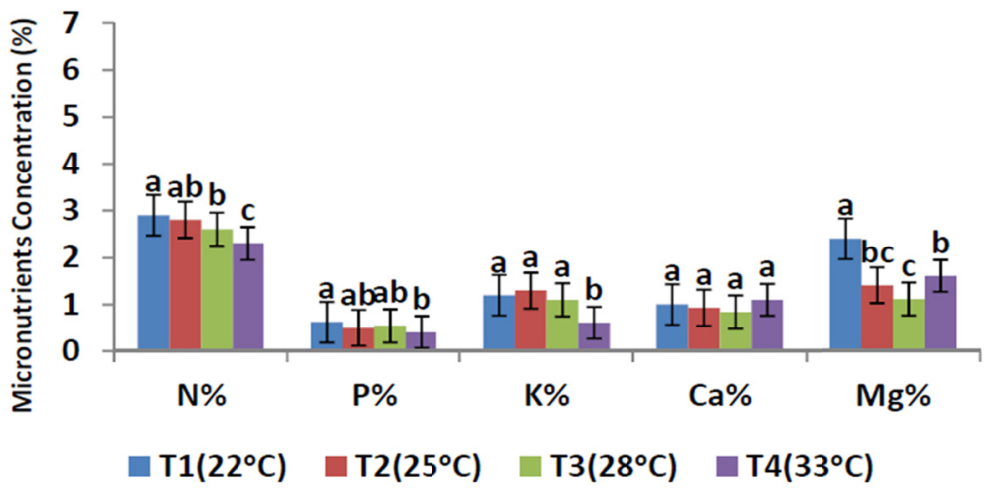

Figure $4 \mathrm{~b}$. Effect of root-zone temperatures on roots nutrient concentration of cucumber plant grown in hydroponic closed system during summer (June-August) in 2017/2018

\section{Discussion}

The present study intends to comprehend the effects of root zone temperatures (RZT) on the growth and development of cucumber plants to ultimately increase the cucumber fruit production in terms of yield and yield related characters, which are discussed here under:

\subsection{Plant Height}

The cucumber plants responded significantly $(\mathrm{p}<0.05)$ highest to the cool root zone temperatures of $22{ }^{\circ} \mathrm{C}$ and $25^{\circ} \mathrm{C}$ at root zones in both years 2016/17 and 2017/18 during summer season which coincides from June to August in Oman as well as all the countries of Arabian Peninsula. Differences in response of cucumber plants from two years in plant height at different root-zone temperatures at different stages of growth of the crop were similar to the study of Moon et al. (2007) where it was observed that during summer the growth rate of the stem of cucumber at both temperatures had been linear for a long time in contrast to the exponential growth found in winter while in autumn and spring the growth rate at $25^{\circ} \mathrm{C}$ was linear. Growth indexes plant height, internode length, root length, and leaf area at low RZT had less difference among nutrient treatments. However, greater response was obtained for different nutrients at high RZT. Yan et al. (2013) showed that root-zone cooling did 
not affect the plant height, number of nodes, and stem weight. Sakamoto and Suzuki (2015) found that root-zone heating at $33{ }^{\circ} \mathrm{C}$ reduced leaf number, shoot length of carrots plants. Veenman and Zoneh (1977) demonstrated that plants of tomato grown at the lowest and the highest root temperatures were fully normal in appearance although their size was smaller than at the optimal temperatures of $20^{\circ} \mathrm{C}$ and $25^{\circ} \mathrm{C}$ (Table 1).

\subsection{Leaf Number/Plant}

As indicated in the results, there were significant $(p<0.05)$ differences in leaf number/plant in both years between the cooled root-zone temperatures of $22{ }^{\circ} \mathrm{C}, 25^{\circ} \mathrm{C}$ and $28{ }^{\circ} \mathrm{C}$ and non cooled root-zone temperature of $33^{\circ} \mathrm{C}$ (control). Veenman and Zoneh (1977) reported that the seasonal effect on leaf number of tomato was much smaller as compared that on plant height. At a root temperature of $25^{\circ} \mathrm{C}$, after 25 days of transplanting, plant height in summer was $42.5 \mathrm{~cm}$ and $9 \mathrm{~cm}$ in winter while leaf number was 14.0 and 8.3 in summer and winter, respectively. No apparent interaction between season and root temperature was observed in leaf number, as was the case with plant height since leaf number was found increased linearly with time. The effect of RTZ on number of leaves /plant was clear at $22^{\circ} \mathrm{C}$ in which the plants produced the highest leaf number in both years, $2016 / 2017$ (30) and 2017/2018 (34) followed by those at $25{ }^{\circ} \mathrm{C}$ (29 and 34) as compared to that at control (27 and 30). The results obtained in the present study are in agreement with Sakamoto and Suzuki (2015) who found that root-zone heating at $33^{\circ} \mathrm{C}$ reduced leaf number and shoot length of carrots plants. Similarly, Moon et al. (2007) revealed that leaves and stem height had slow growth rate as root-zone temperature was increased after 7 and 14 days of planting. Further, Masaru et al. (2016) on strawberry showed that the number of newly emerging leaves was found increased in plants cooled at root zone.

\subsection{Leaf Area $\left(\mathrm{cm}^{2}\right)$}

The results of the present study indicated significant $(\mathrm{p}<0.05)$ effects in leaf area between plants of cooled RZT of $22{ }^{\circ} \mathrm{C}, 25^{\circ} \mathrm{C}$ and $28^{\circ} \mathrm{C}$ with higher leaf area in comparison with non-cooled RZT $33^{\circ} \mathrm{C}$ (control) in both years 2016/2017 and 2017/2018. This could be due to the fact that RZT influences the vegetative growth and biomass of the plant (Zhang et al., 2008; Chadirin et al., 2011; Sakamoto \& Suzuki, 2015a, 2015b) and leaf area is indirectly associated with the rate of photosynthesis and amount of assimilation rate in the plants (Pang et al., 1997; Lu et al., 1994). Yan et al. (2013) reported that strong interactions were observed between RZT and nutrients on leaf area and concluded that higher biomass and growth of cucumber seedlings were produced at RZT of $20^{\circ} \mathrm{C}$. Further, Xiaolei and Zhifeng (2004) found that optimal LAI from 3 to 3.5 could balance the photosynthetic capacity per unit area, light penetration and air circulation and could increase the yield in plastic greenhouse. On the contrary, in respect of the effect of higher RZT, it was found that leaves of cucumber at $35^{\circ} \mathrm{C}$ root-zone temperature(RZT) were severely affected with small area and burn in plants (Moon et al., 2007).

\subsection{Chlorophyll Content}

In the present study, the results showed significant effects of the RZT on chlorophyll content as SPAD values in both years. Higher values were linked to lower RZT viz. $22{ }^{\circ} \mathrm{C}$ to $28{ }^{\circ} \mathrm{C}$. Many studies revealed that high temperature can affect physiological process such as chlorophyll content and subsequently metabolism of plant. Heat stress not only causes an imbalance in plant metabolism and disruption of cellular homeostasis resulting in deleterious damage to plant cells (Suzuki \& Mittler, 2005) but also triggers significant alternations in plant physiological processes, such as water uptake and leaf photosynthesis (Suzuki et al., 2008; He et al., 2013). Masaru et al. (2016) found that high RZT treatment induced plants withering within two months or decreased the chlorophyll content as expressed by the SPAD value.

\subsection{Fruit Number $/ m^{2}$}

Cooling of RZT of cucumber significantly showed positive effect in fruit numbers $/ \mathrm{m}^{2}$ in both years, 2016/2017 and 2017/2018 as compared to non-cooled control. Moon et al. (2007) found that severe growth and development inhibition by high temperature in summer in cucumber. High temperature in a greenhouse during summer inhibits crop growth especially high RZT accompanied with high air temperature (Song, 2013). The highest fruit number $/ \mathrm{m}^{2}$ was produced by plants of cooled RZT and the lowest was given by non-cooled RZT. Our findings are in agreement with those of Moon et al. (2007) who reported that the number of fruits per plant was 15.9 in non-cooled root-zone and 19.3 in cooled root-zone.

\subsection{Yield}

The results of present study indicated that cooled nutrient solution temperatures that reflect root-zone atmosphere of cucumber during summer season can improve the growth as well as the yield of cucumber. It is well understood that environmental stress can affect plant development; growth and yield. Root-zone temperature is the important factor which can affect plant growth, yield, uptake of water and nutrient uptake 
(Stoltzfus et al., 1998; Lahti et al., 2005; Solfjeld \& Johnsen, 2006; Diaz-Perez et al., 2007). In the present study all the plants of cooled RZT $22{ }^{\circ} \mathrm{C}, 25^{\circ} \mathrm{C}$ and $28{ }^{\circ} \mathrm{C}$ produced higher yield as compared to plants of non-cooled RZT, $33^{\circ} \mathrm{C}$ in both years 2016/2017 and 2017/2018. Our results are in agreement with Moon et al. (2007) who found the most remarkable effect of root-zone cooling in terms of increase in yield of cucumber as compared to cucumber grown in non-cooled root-zone. Similarly, Lee (1994) reported that as the plants grow, the fruit yield of cucumber proportionally decreases with increased root-zone temperature. However, these results are in contrast to those of Gent and Ma (1998) who obtained better yield of tomato by using a forced-air heater applied to root-zone for several regimes of daily temperature. Urrestarazu et al. (2008) revealed that lesser effects were observed at root-zone temperature between $18-22{ }^{\circ} \mathrm{C}$ concerning yield and fruit quality parameters in rockwool grown melon. Number of fruits and fruit size (fresh weight) of strawberry tended to increase by root-zone cooling treatments (Sakamoto et al., 2016). Mawgoud et al. (2005) revealed positive effect of heating on production of pepper with $39 \%$ to $76 \%$ increases in yields due to an increase in both fruit number and average fruit weight. The vegetative growth was improved by increasing leaf area and plant height in cooled plants as compared to non-cooled ones with increase in fruit yield (Fujishige et al., 1991; Nkansah \& Ito, 1994). In addition, Sasaki and Itagi (1989) reported that fruit yield was increased by root-zone cooling at $20^{\circ} \mathrm{C}$ in summer tomato production. Lee (1996) reported that yield of cucumber fruits was highest from March to June, and from September to November but lowest in summer and winter season, especially in July and August in Korea. Similarly, Lee (1994) and Du and Tachibana (1994a, 1994b) revealed that high temperature in summer and low temperature in winter are the main factors in reducing productivity in the year-round cultivation of cucumber. The authors reported that below $12-13{ }^{\circ} \mathrm{C}$ RZT, growth was suspended and over $35{ }^{\circ} \mathrm{C}$ RZT, growth was inhibited. In Oman, low yields in summer have been reported during May- July period of the year according to the report of the Public Authority for Civil Aviation Authority (PACA, 2016) and reports from other Arabian Peninsula countries. The present findings suggested that cooled root-zone of cucumber through cooled nutrient solution temperature increased yield of cucumber during summer.

\subsection{Shoot \& Root Fresh Weight}

Although suboptimal root-zone temperature tends to restrict plant growth, responsiveness of plants to root-zone temperature depends on the plant species. For instance, six cucurbitaceous species exhibited different responses in the form of changes of biomass, photosynthesis, and stomatal conductance at RZT between $14{ }^{\circ} \mathrm{C}$ and $34{ }^{\circ} \mathrm{C}$ (Zhang et al., 2008). In the present study, cool RZT had positive effects on both shoot and root fresh weights in both the years although second year was not significant. Similar results were proved by Daskalaki \& Burrage (1997) who found that shoot fresh weight was the highest at $28^{\circ} \mathrm{C}$ and lowest at $12{ }^{\circ} \mathrm{C}$ whereas in other study with muskmelon, it was reported that plant fresh weight gain was the highest at the $25^{\circ} \mathrm{C}$ RZT (Rhonda \& Stoltzfus, 2008). Adebooye et al. (2009) observed that RZT of $20^{\circ} \mathrm{C}$ and $25^{\circ} \mathrm{C}$ produced significantly $(\mathrm{p} \leq 0.05)$ increased effects on the average number of tendrils, number of leaves, fresh leaf weight, stem length, fresh stem weight, root length, fresh root weight and root volume as compared to those at $30^{\circ} \mathrm{C}$. Recently, Sun et al. (2016) reported that RZ cooling increased shoot fresh weight, root fresh weight, shoot dry weight, root dry weight, total plant fresh weight, and total plant dry weight in lettuce by $8.9,20.5,7.8,14.3,9.7$, and $8.5 \%$, respectively.

\subsection{Shoot \& Root Dry Weight}

The results of the present study showed similar response of cucumber plants to cooled RZT in terms of shoot and root dry weigh as shown in terms of shoot and root fresh weights. Plants at cooled RZT of $25{ }^{\circ} \mathrm{C}$ and $22{ }^{\circ} \mathrm{C}$ produced higher shoot and root dry biomass as compared to non-cooled root-zone temperature of $33{ }^{\circ} \mathrm{C}$ in both years although shoot dry weight was not significant in second year. James et al. (2008) found that root and shoot dry weight, rate of shoot growth, plant height, and water use peaked at $25^{\circ} \mathrm{C}$. Yan et al. (2013) reported that plant dry weights were suppressed at low RZT of $12^{\circ} \mathrm{C}$ while higher biomass and growth of cucumber seedlings were produced at elevated RZT of $20^{\circ} \mathrm{C}$ under each nutrient treatment. Growth indexes (plant height, internode length, root length, and leaf area) at $12{ }^{\circ} \mathrm{C}$-RZT had less difference among nutrient treatments but greater response was obtained for different nutrients at high RZT. Sun et al. (2016) demonstrated the feasibility of cultivating hydroponic lettuce in high-temperature season through cooling of the nutrient solution. Similarly, the results obtained by other researchers (Zhang et al., 2008; Chadirin et al., 2011; Sakamoto \& Suzuki, 2015a, 2015b) showed the positive influence of root zone temperature on both the vegetative growth and biomass of the plant similar to the results of the present study.

\subsection{Nutrients Concentration and Uptake in Shoot and Root}

Mineral nutrition of plants plays a crucial role in increasing resistance to environmental stresses (Marschner, 1995). In the present study, responses of shoots and roots to root-zone temperatures (RZT) were significantly (p 
$<0.05$ ) affected by cooled RZT at $22{ }^{\circ} \mathrm{C}, 25{ }^{\circ} \mathrm{C}$ and $28{ }^{\circ} \mathrm{C}$ as compared to uncooled RZT $33{ }^{\circ} \mathrm{C}$ in both years, 2016/2017 and 2017/2018. The concentration and uptake of mineral elements in the cucumber shoot and root were strongly affected by the interacting effects of root-zone temperature (RZT). Nevertheless, not all elements were affected to same extent. Total N, P, K, Ca, and Mg uptakes were found promoted at RZT of $22{ }^{\circ} \mathrm{C}, 25^{\circ} \mathrm{C}$ and $28{ }^{\circ} \mathrm{C}$ as compared to that in non-cooled RZT of $33^{\circ} \mathrm{C}$. This was also noted by earlier researchers. The shoot and roots mineral element uptake was increased with elevated root temperature which promoted plant nutrient uptake by (1) increasing new root formation (Daskalaki \& Burrage, 1997; Domisch et al., 2002), (2) changing root physiology and improving nutrient uptake (Carey \& Berry, 1978; Marschner 1990; Kozlowski \& Pallardy, 1997), and (3) accelerating nutrient mineralization in soil (Domisch et al., 2002). Wan et al. (1999) reported that the root growth of trembling aspen seedlings at $10{ }^{\circ} \mathrm{C}$ was lower than that at $20^{\circ} \mathrm{C}$ soil temperature. The higher nutrient distribution ratio in shoots at $20^{\circ} \mathrm{C}$-RZT resulted in increased stem growth and higher shoots nutrients concentrations (Lahti et al., 2005). Yan et al. (2012) found that differences in nutrient uptake were existed between species as affected by RZT such as increasing solution temperature at $14{ }^{\circ} \mathrm{C}$ and $20{ }^{\circ} \mathrm{C}$ in cucumbers which showed an increased $\mathrm{NO}_{3}$ uptake with no effect on phosphate uptake as compared to unheated treatment. Urrestarazu et al. (2008) reported that increasing nutrient solution temperature to $18-22{ }^{\circ} \mathrm{C}$ increased phosphate uptake in two substrates in cucumber. In the present study, significant effect of phosphate uptake was observed in all the cooled RZT as compared to non-cooled RZT in the roots while no significant effect was observed in shoot of cucumber plant in both years. The results of the present study indicated that cooled nutrient solution temperature had positive effect on shoot and root growth and nutrient uptake. In this respect, Rhonda et al.(2008) reported that root $\mathrm{P}$ and $\mathrm{Zn}$ concentrations increased linearly with increasing RZT while Daskalaki and Burrage (1998) showed that uptake of all nutrients (N, P, calcium (Ca), and K) could be promoted significantly when root temperature was increased from $12{ }^{\circ} \mathrm{C}$ to $20^{\circ} \mathrm{C}$ in cucumber. Hood and Mills (1994) also found RZT of $22{ }^{\circ} \mathrm{C}$ produced higher growth and nutrient uptake in snapdragon (Antirrhinum majus L. Peoria') as compared to that of $8{ }^{\circ} \mathrm{C}$ and $15{ }^{\circ} \mathrm{C}$. Similarly, with regard to potassium the crop was found responding positively at cooled RZTs than that of non-cooled RZT in uptake of potassium in shoots and roots of cucumber. In the present study, cooled RZT at $22{ }^{\circ} \mathrm{C}$ and $25^{\circ} \mathrm{C}$ accumulated more potassium as compared to non-cooled RZT of $33{ }^{\circ} \mathrm{C}$ athough it was not significant effect in root potassium uptake in second year. These findings are in line with Gosselin and Trudel (1983) who demonstrated that raising the RZT to $24^{\circ} \mathrm{C}$ increased the shoot $\mathrm{P}$ and $\mathrm{K}$ concentrations in tomato as compared to those at $12{ }^{\circ} \mathrm{C}$ or $15{ }^{\circ} \mathrm{C}$. Cooling of root-zone temperature did not significantly affect magnesium concentrations and uptake. Tan et al. (2006) showed that total shoot and root $\mathrm{NO}_{3}, \mathrm{~K}, \mathrm{Ca}, \mathrm{Cu}, \mathrm{Fe}, \mathrm{Mg}, \mathrm{Mn}$, and $\mathrm{Zn}$ accumulation of $20^{\circ} \mathrm{C}$-RZT plants were more than the plants having RZT more than $20^{\circ} \mathrm{C}$ which suffered from a reduction of total mineral accumulation. Similar trend was noticed in our study in respect of shoot and root calcium uptake which was positively influenced by cooled RZTs with significant $(\mathrm{p}<0.05)$ differences. Yan et al. (2012) demonstrated that more nutrients are accumulated in roots and less is transported to shoots at 10 ${ }^{0} \mathrm{C}$-RZT as compared to those at $20{ }^{\circ} \mathrm{C}$-RZT, which are similar to our observations. James et al. (2008) demonstrated that uptake of all mineral elements was significantly different with each temperature treatment except for B, Fe, and Mo which did not respond to temperature.

\section{Conclusion}

It is concluded that high air temperature and root-zone temperatures (RZT) in summer season can suppress or decrease the biomass, nutrient uptake and growth of cucumber. The results showed that the cooled root-zone temperatures (RZT) of $22{ }^{\circ} \mathrm{C}$ and $25^{\circ} \mathrm{C}$ improved growth characters (plant height, leaf number, chlorophyll content, leaf area) and uptake of nutrients. The productivity of cucumber was found increased at cooled RZT of $22{ }^{\circ} \mathrm{C}$ by $74.3 \%$ and at $25^{\circ} \mathrm{C}$ by $71.4 \%$ as compared to the yield at non-cooled RZT of $33^{\circ} \mathrm{C}$. Therefore, cooling of root-zone temperatures through nutrient solution is very essential during summer period for improved yield in cucumber.

\section{Acknowledgements}

The authors' expresses are grateful to the financial grants of Agriculture and Fisheries Development Fund (AFSF) of the Ministry of Agriculture \& Fisheries for the research project leading to Ph.D. degree of the main author who also thank the Director General of Agriculture \& Livestock Research, Director of Plant Production Research Center and Director of Soil and Water Research Center for their supports in logistics and facilities to conduct several experiments. Thanks are also to the advisor, members of the advisory committee and all the concerned staff of the College of Agriculture \& Marine Sciences and Directorate General of Agriculture \& Livestock Research (DGALR) who have directly and indirectly assisted in conducting the experiments of the research project. 


\section{References}

Abdel-Mawgoud, A. M. R., Sassine, Y. N., El-Behairy, U., Abou-Hadid, A. F., \& El-Abd, S. O. (2005). Effect of Minimum Root-zone Temperature on the Growth and Production of Greenhouse Sweet Pepper. Journal of Applied Sciences Research, 1(1), 72-77.

Adebooye, O. C., Schmitz-Eiberger, M., Lankes, C., \& Noga, G. J. (2010). Inhibitory effects of sub-optimal rootzone temperature on leaf bioactive components, photosystem II (PS II) and minerals uptake in Trichosanthes cucumerina L. Cucurbitaceae. Acta Physiologiae Plantarum, 32, 67-73. https://doi.org/ 10.1007/s11738-009-0379-z

Al-Rawahy, M., Al-Rawahy, S., Al-Mulla, Y., \& Nadaf, S. K. (2018). Impact of Rhizosphere's Thermal Change on the Development and Production of Hydroponically Grown Cucumber under Controlled Environment. Asian Journal of Agriculture and Food Sciences, 6, 152-165.

Carey, R. W., \& Berry, J. A. (1978). Effects of low temperature on respiration and uptake of rubidium ions by excised barley and corn roots. Plant Physiol., 61, 858-860. https://doi.org/10.1104/pp.61.5.858

Chadirin, Y., Hidaka, K., Takahashi, T., Sago, Y., Wajima, T., \& Kitano, M. (2011). Application of temperature stress to roots of spinach: I. Effect of the low temperature stress on quality. Environment Control in Biology, 49, 133-139. https://doi.org/10.2525/ecb.49.133

Daskalaki, A., \& Burrage, S. W. (1997). The effect of root zone temperature on the growth and root anatomy of cucumber (Cucumis sativus L.). Acta. Hortic., 449, 569-574. https://doi.org/10.17660/ActaHortic.1997. 449.79

Daskalaki, A., \& Burrage, S.W. (1998). Solution temperature and the uptake of water and nutrients by cucumber (Cucumis sartivas L.) in hydroponics. Acta. Hortic., 458, 317-322. https://doi.org/10.17660/ActaHortic.1998. 458.40

Domisch, T., Fine, R. L., Lehto, T., \& Smolander, A. (2002). Effects of soil temperature on nutrient allocation and mycorrhizas in Scots pine seedlings. Plant Soil, 239, 173-185. https://doi.org/10.1023/A:1015037127126

Du, Y. C., \& Tachibana, S. (1994a). Effect of supraoptimal root temperature on the growth, root respiration and sugar content of cucumber plants. Scientia Hort., 58, 289-301. https://doi.org/10.1016/0304-4238(94) 90099-X

Du, Y. C., \& Tachibana, S. (1994b). Photosynthesis, photosynthate translocation and metabolism in cucumber roots held at supraoptimal temperature. J. Japan. Soc. Hort. Sci., 63, 401-408. https://doi.org/10.2503/jjshs. 63.401

Fujishige, N., Sugiyama, T., \& Ogata, R. (1991). Effect of root temperature on the flower formation and fruit yield of tomatoes. J. Japan. Soc. Hort. Sci., 60, 97-103. https://doi.org /10.2503/jjshs.60.97

Gent, M. P. N., \& Ma, Y. Z. (1998). Diurnal temperature variation of the root and shoot affects yield of greenhouse tomato. Hort Sci., 33, 47-51.

Giuffrida. F., Heuvelink, E., \& Stanghellini, C. (2008). Effect of Root-zone nutrient concentration on cucumber growth in roockwool. Acta Hort., 801. https://doi.org/10.17660/ActaHortic.2008.801.126

Gossenlin, A., \& Trudel, M. J. (1983). Interactions between air and root temperatures on greenhouse tomato. II: Mineral composition of plants. J. Am. Soc. Hort. Sci., 108, 905-909.

He, J., Qin, L., \& Lee, S. K. (2013). Root-zone CO2 and root-zone temperature effects on photosynthesis and nitrogen metabolism of aeroponically grown lettuce (Lactuca sativa L.) in the tropics. Photosynthetica, 51, 330-340. https://doi.org/10.1007/s11099-013-0030-5

Hood, T. M., \& Mills, H. A. (1994). Root-zone temperature affects nutrient uptake and growth of snapdragon. $J$. Plant Nutr., 17, 279-291. https://doi.org/10.1080/01904169409364727

Tindall, J. A., Mills, H. A., \& Radcliffe, D. E. (2008). The effect of root zone temperature on nutrient uptake of tomato. Journal of Plant Nutrition, 13(8), 939-956. https://doi.org/10.1080/01904169009364127

Jinan, P., Ma, D., \& Li, S. (1997). Studies on cucumber photosynthesis. Tianjin Agri. Sci, 12, 15-18.

Kaplan, F., Kopka, J., Haskell, D. W., Zhao, W., Schiller, K. C., Gatzke, N., \& Guy, C. L. (2004). Exploring the temperature-stress metabolome of arabidopsis. Plant Physiology, 136, 4159-4168. https://doi.org/10.1104/ pp. 104.052142 
Kozlowski, T. T., \& Pallardy, S. G. (1997). Mineral nutrition. In T. T. Kozlowski, \& S. G. Pallardy (Eds.), Physiology of Woody Plants (pp. 210-250). Academic Press, San Diego. https://doi.org/10.1016/B978-012 424162-6/50027-2

Lahti, M., Aphalo, P. J., Fine, R. L., Ryyppo, A., Lehto, T., \& Mannerkoski, H. (2005). Effects of soil temperature on shoot and root growth and nutrient uptake of 5-yearold Norway spruce seedlings. Tree Physiol., 25, 115-122. https://doi.org/10.1093/treephys/25.1.115

Lee, W. S. (1994). Garlic in: Vegetables of Korea. Korean J Genet, 24, 75-81.

Li, L. (2011). The influence of different temperature on the rhizosphere to growth of tomato (M.Sc. Dissertation, Shanxi Agricultural University).

Lyr, H., \& Garbe, V. (1995). Influence of root temperature on growth of Pinus sylvestris, Fagus sylvatica, Tilia cordata and Quercus robur. Trees, 9, 220-223. https://doi.org/10.1007/BF00195276

Malik, S., Andrade, S. A., Sawaya, A. C. H. F., Bottcher, A., Mazzafera, P. (2013). Root-zone temperaturealters alkaloid synthesis and accumulation in Catharanthus roseus and Nicotiana tabacum. Industrial Crops and Products, 49, 318-325. https://doi.org/10.1016/j.indcrop.2013.05.009

Marschner, H. (1990). Nutrient availability in soils. In H. Marschner (Ed.), Mineral Nutrition of Higher Plants (pp. 500-503). Academic Press, London.

Marschner, H., Kirkby, E. A., \& Cakmak, I. (1996). Effect of mineral nutritional status on shoot-root partitioning of photoassimilates and cycling of mineral nutrients. J. Exp. Bot., 47, 1255-1263. https://doi.org/10.1093/ $\mathrm{jxb} / 47$. Special_Issue.1255

Moon, J. H., Kang, Y. K., \& Suh, H. D. (2007). Effect of root-zone cooling on the growth and yield of cucumber at supraoptimal air temperature. Acta Hort., 761, 271-274. https://doi.org/10.17660/ActaHortic.2007.761.36

Moon, J. H., Hee, O. B., \& Jang, I. K. (2007). Effect of root-zone temperature on water relation and hormone content in cucumber. Hort. Environ. Biotechnology, 48(5), 1-8.

Mozafar, A., Schreiber, P., \& Oertli, J. J. (1993). Photoperiod and root-zone temperature: Interacting effects on growth and mineral nutrients of maize. Plant Soil, 153, 71-78. https://doi.org/10.1007/BF00010545

Nkansah, G. O., \& Ito, T. (1994). Comparative studies on growth and development of heat-tolerant and non heat-torelant tomato plants grown at different root-zone temperatures. J. Japan. Soc. Hort. Sci., 62, 775-780. https://doi.org/10.2503/jjshs.62.775

Nxawe, S., Laubscher, C. P., \& Ndakidemi, P. A. (2009). Effect of regulated irrigation water temperature on hydroponics production of spinach (Spinacia oleracea L.). Afr. J. Agr. Res., 4, 1442-1446.

Peykanpour, E., Ghehsareh, A. M., Fallahzade, J., \& Najarian, M. (2016). Interactive effects of salinity and ozonated water on yield components of cucumber. Plant Soil Environ, 62, 361-366. https://doi.org/ 10.17221/170/2016-PSE

PACA (Public Authority for Civil Aviation Authority). (2016). General Weather Forecast. Directorate General of Meteorology, Sultanate of Oman.

Ramakrishna, A., \& Ravishankar, G. A. (2011). Influence of abiotic stress signals on secondary metabolites in plants. Plant Signaling \& Behavior, 6, 1720-1731. https://doi.org/10.4161/psb.6.11.17613

Rhonda, M., Stoltzfus, B., Taber, H. G., \& Aiello, A. S. (2008). Effect of increasing root-zone temperature on growth and nutrient uptake by 'gold star' muskmelon plants. Journal of Plant Nutrition, 21(2), 321-328.

Sakamoto, M., \& Suzuki, T. (2015). Elevated root-zone temperature modulates growth and quality of hydroponically grown Carrots. Agriculture Sciences, 6, 745-757.

Sakamoto, M., \& Suzuki, T. (2015a). Elevated root-zone temperature modulates growth and quality of hydroponically grown carrots. Agricultural Sciences, 6, 749-757. https://doi.org/10.4236/as.2015.68072

Sakamoto, M., \& Suzuki, T. (2015b). Effect of root-zone temperature on growth and quality of hydroponically grown red leaf lettuce (Lactuca sativa L. cv. Red Wave). American Journal of Plant Sciences, 6, 2350-2360. https://doi.org/10.4236/ajps.2015.614238

Sakamoto, M., Uenishi, M., Miyamoto, K., \& Suzuki, T. (2016). Effect of root-zone temperature on the growth and fruit quality of hydroponically grown strawberry plants. Journal of Agricultural Science, 8, 122-131. https://doi.org/10.5539/jas.v8n5p122 
Sasaki, K., \& Itagi, T. (1989). Effect of root cooling treatment of nutrient solution on growth and yield of tomato, cucumber and melon. Environ. Control Biol., 27, 89-95. https://doi.org/10.2525/ecb1963.27.89

Solfjeld, I., \& Johnsen, O. (2006). The influence of root-zone temperature on growth of Betula pendula Roth. Trees, 20(3), 320-328. https://doi.org/10.1007/s00468-005-0043-1

Song, M. (2013). Influence of rhizosphere temperature on growth, development and physiological metabolism of greenhouse tomato in summer (Ph.D. Dissertation, Shanxi Agricultural University).

Sun, J., Lu, N., Xu, H., Maruo, T., \& Guo, S. (2016). Root zone cooling and exogenous spermidine root-pretreatment promoting Lactuca sativa L. growth and photosynthesis in the high-temperature season. Front. Plant Sci., 7, 368. https://doi.org/10.3389/fpls.2016.00368

Suzuki, K., Nagasuga, K., \& Okada, M. (2008). The chilling injury induced by high root temperature in the leaves of rice seedlings. Plant \& Cell Physiology, 49, 433-442. https://doi.org/10.1093/pcp/pcn020

Suzuki, N., \& Mittler, R. (2005). Reactive oxygen species and temperature stresses: A delicate balance between signaling and destruction. Physiologia Plantarum, 126, 45-51. https://doi.org/10.1111/j.0031-9317. 2005.00582.x

Tan, L. P., He, J., \& Lee, S. K. (2006). Effects of root-zone temperature on the root development and nutrient uptake of Lactuca sativa L. "Panama" grown in an aeroponic system in the tropics. Journal of plant nutrition, 25, 297-314. https://doi.org/10.1081/PLN-100108837

Urrestarazu, M., Salas, M. C., Valera, D., Gome, A., \& Mazuela, P. C. (2008). Effects of heating nutrient solution on water and mineral uptake and early yield of two cucurbits under soilless culture. J. Plant Nutr., 31, 527-538 https://doi.org/10.1080/01904160801895068

Veenman, H., \& Zonen, B. V. (1977). Root temperature and growth of young Tomato plants. The Netherlands Publication, 443. Department of Horticulture, Agricultural University, Wageningen.

VSN International. (2011). GenStat for Windows (14th ed.). VSN International, Hemel Hempstead, UK.

Wan, X. C., Landha, S. M., Zwiazek, J. J., Lieffers, V. J. (1999). Root water flow and growth of aspen (Populus tremuloides) at low root temperatures. Tree Physiol., 19, 879-884. https://doi.org/10.1093/treephys/19.13.879

Xiaolei, S., \& Zhifeng, W. (2004). The optimal leaf area index for cucumber photosynthesis and production in plastic greenhouse. Acta Hortic, 633, 161-165. https://doi.org/10.17660/ActaHortic.2004.633.19

Yan, Q., Duan, Z., Mao, J., Xun, L., \& Dong, F. (2012). Effects of root-zone temperature and N, P, and K supplies on nutrient uptake of cucumber (Cucumis sativus L.) seedlings in hydroponics. Soil Science and Plant Nutrition, 58, 707-717. https://doi.org/10.1080/00380768.2012.733925

Yan, Q., Duan, Z., Mao, J., Xun, L., \& Fei, D. (2013). Low root zone temperature limits nutrient effects on cucumber seedling growth and induces adversity physiological response. Journal of Integrative Agriculture, 12, 1450-1460. https://doi.org/10.1016/S2095-3119(13)60549-3

Youssef, N., Abu El-Azm, A. I., \& AbdElhady, S. A. (2017). Frequent Foliar Sprayings of Salicylic Acid with Elevated Concentrations Enhance Growth, Yield and Fruit Quality of Strawberry (Fragaria x ananassa Duch. cv. Festival) Plants. Egypt. J. Hort., 44, 61-74. https://doi.org/10.21608/ejoh.2017.1100.1008

Yuhua, L., Shen, Y., \& Chen, L. (1994). Photosynthesis of single cucumber leaves. Acta Hort. Sinica, 21(1), 54-58.

Zhang, Y. P., Qiao, Y. X., Zhang, Y. L., Zhou, Y. H., \& Yu, J. Q. (2008). Effects of root temperature on leaf gas exchange and xylem sap abscisic acid concentrations in six Cucurbitaceae species. Photosynthetica, 46, 356-362. https://doi.org/10.1007/s11099-008-0065-1

Zobayed, S. M. A., Afreen, F., \& Kozai, T. (2005). Temperature stress can alter the photosynthetic efficiency and secondary metabolite concentrations in St. John's Wort. Plant Physiology and Biochemistry, 43, 977-984. https://doi.org/10.1016/j.plaphy.2005.07.013

\section{Copyrights}

Copyright for this article is retained by the author(s), with first publication rights granted to the journal.

This is an open-access article distributed under the terms and conditions of the Creative Commons Attribution license (http://creativecommons.org/licenses/by/4.0/). 